\title{
The path to outcome delivery: Interplay of service market strategy and open business models
}

\author{
Ivanka Visnjic $^{\mathrm{a}}$, Andy Neely ${ }^{\mathrm{b}}$, Marin Jovanovic ${ }^{\mathrm{c}, \mathrm{d}, *}$ \\ ${ }^{a}$ Department of Operations, Innovation and Data Sciences, ESADE Business School, Ramon Llull University, Av. Pedralbes, 60-62, 08034 Barcelona, Spain \\ ${ }^{\mathrm{b}}$ Institute for Manufacturing, Department of Engineering, University of Cambridge, 17 Charles Babbage Road, Cambridge CB3 OFS, UK \\ ${ }^{c}$ Department of Industrial Economics and Management, KTH Royal Institute of Technology, Lindstedtsvägen 30, SE-100 44 Stockholm, Sweden \\ d Escuela Técnica Superior de Ingenieros Industriales, Universidad Politécnica de Madrid, c/ José Gutiérrez Abascal, 2, 28006 Madrid, Spain
}

\section{A R T I C L E I N F O}

\section{Keywords:}

Service market strategy

Open business models

Outcome-based contracts

Service innovation

Servitization

\begin{abstract}
A B S T R A C T
Firms in a variety of manufacturing sectors as well as the software industry have increasingly embraced services alongside their product portfolios in order to improve financial performance. Yet, the key question "How do service market strategy change and the accompanying business model change interact, and how does their interplay affect value creation?" remains open. Relying on twelve case studies of firms that have shifted towards providing highly advanced services (e.g. outcome-based contracts), theoretical propositions concerning the interplay of market strategy and business model on value creation are derived. The firms studied report two interdependent changes: first, they evolve the market strategy from provision of pure products to provision of services and then outcomes, in order to achieve a better fit with customer needs and to grow their service businesses. Second, they rely increasingly on partners and suppliers to provide new activities that are outside their competence base. This 'open business model' allows them to grow their new service businesses effectively and efficiently. At the same time, however, the shift to a service market strategy requires enhanced accountability to customers and increases the threat of penalties in the case of failure, while reliance on partners and suppliers leads to loss of control over the activity system and increases the threat of failure due to third party dependency. Thus, this paper finds that the success of firms that shift to services and outcomes hinges on their ability to balance the trade-off between increased value (i.e. growth, efficiency and effectiveness) and increased uncertainty associated with service market strategy/open business model interplay.
\end{abstract}

\section{Introduction}

The shift to provision of services - often referred to as servitization became a prominent trend in a number of industries (Rabetino et al., 2018; Cusumano et al., 2015; Vandermerwe and Rada, 1988). Manufacturing and software firms have pursued service market strategy in order to achieve differentiation in increasingly commoditized product markets and increase their financial performance (Cusumano et al., 2015). For instance, industrial manufacturers such as Caterpillar and Atlas Copco offer maintenance and monitoring services for their equipment. A biopharmaceutical company, Pfizer, complements its products with a range of healthcare solutions that range from patient diagnostic tools to the tools that help track patient compliance with medications.

The most advanced stage of this shift to services is an outcomebased market strategy, whereby the firm guarantees the outcome (result) that the customer requires and combines diverse products with the service offer (Ng et al., 2013; Suarez et al., 2013; Visnjic et al., 2017). For instance, GE Aviation, a subsidiary of General Electric, and RollsRoyce, the aerospace and defense company, began as manufacturers of airplane engines (product), then included services such as maintenance in their portfolio (product plus service), and finally shifted into selling 'flying hours' by guaranteeing the availability of their engines (outcome) (Ng et al., 2013; Batista et al., 2016; Howard et al., 2016).

Most scholars agree that services and outcomes create higher value for the customer and, consequently, firms create growth opportunities pursuing these strategies (Sawhney et al., 2004; Fang et al., 2008; Visnjic Kastalli and Van Looy, 2013; Kowalkowski et al., 2017). However, for the service and, especially, the outcome-based market strategy to be executed effectively and efficiently, it needs to be accompanied by change in the business model used to deliver the service or outcome (Forkmann et al., 2017b; Kindström, 2010; Visnjic et al., 2016).

It remains unclear what this business model change entails and how value creation is affected by it. Consequently, the interdependencies

\footnotetext{
* Corresponding author at: Department of Industrial Economics and Management, KTH Royal Institute of Technology, Lindstedtsvägen 30 , SE-100 44 Stockholm, Sweden.

E-mail addresses: ivanka.visnjic@esade.edu (I. Visnjic), adn1000@cam.ac.uk (A. Neely), marinjo@kth.se (M. Jovanovic).
} 
between a shift to service market strategy and a change in the business model, including their combined impact on value creation, are not well understood (Forkmann et al., 2017a; Hacklin et al., 2017; Visnjic et al., 2017; Zott and Amit, 2008).

This is, indeed, an important concern and represents a gap in the literature, especially since empirical evidence suggests that a shift into services can represent an implementation challenge that not only results in faltering growth but also destroys value (Fang et al., 2008; Visnjic et al., 2017), damages the firm's performance (Kohtamäki et al., 2013; Suarez et al., 2013; Visnjic Kastalli et al., 2013; Josephson et al., 2016) and ultimately risks firm survival (Benedettini et al., 2015).

Thus, the question addressed in this research is: "How do market strategy change and business model change interact in response to the shift into services and outcomes, and how does their interplay affect value creation?" To answer this question, we studied 12 firms (11 manufacturers and software providers, and one pure service provider) from 6 diverse sectors that shifted to services and outcomes. As expected, the results show that firms gradually extended their market portfolios to provide additional services, ultimately guaranteeing the provision of outcomes. As firms progressed along this path, the range of activities that needed to be executed in order to deliver the additional services, and to ultimately guarantee outcomes, also increased. As some of these activities lay outside their competency base or could be delivered more efficiently by other firms, they were forced to collaborate with partners and outsource to suppliers, thereby 'opening up' their business models (Chesbrough, 2007, 2010, 2012; Tushman et al., 2012; Kortmann and Piller, 2016) so as to deliver those services effectively and efficiently (Zott and Amit, 2008; Gawer, 2014).

The simultaneous shift to service market strategy and the opening up of the business model carries two implications. On the one hand, embracing service market strategy grows the service business, whilst opening up the business model increases the effectiveness and efficiency. Thus, the interplay of service market strategy and open business model creates value yet, it also increases risks and uncertainties. For instance, embracing an outcome-based market strategy implies accountability to the customer's outcome and the imposition of penalties if those outcomes are not met. At the same time, opening up the business model implies less control over the activity system for the firm and greater risk of partner/supplier opportunism or failure to coordinate activities with them. This paper refers to this value creation and accumulation of risks and uncertainties as 'accountability spread', and argues that the ability to find the market strategy/business model combination that optimizes the trade-off between increase in value creation and increase in risks and uncertainties may determine the sustainability of servitization.

\section{Theoretical foundations}

\subsection{Shift from product to service market strategy}

Some product-centric firms have embarked on an extensive shift into services over recent decades (Neely, 2008; Santamaría et al., 2012; Baines et al., 2017). As products became more commoditized, service offerings came to represent a means of differentiation (Bharadwaj et al., 1993; Wise and Baumgartner, 1999; Ulaga and Eggert, 2006; Antioco et al., 2008), particularly in mature industries (Cusumano et al., 2015). Consequently, manufacturers and software providers began gradually to create value by providing services more efficiently and/or capitalizing on the complementarities between products and services (Anderson and Narus, 1995; Visnjic et al., 2016) and growing the service business (Visnjic Kastalli et al., 2013; Kowalkowski et al., 2017).

As a result, firms are broadening the range of services offered with the provision of outcome-based service as the most advanced service stage (Jovanovic et al., 2016; Ng et al., 2013; Visnjic et al., 2017). Outcome delivery entails offering guarantees to deliver specific outcomes required by the customer, where the firm coordinates provision of diverse products and services necessary to ensure that performance is delivered (i.e. maintenance and repairs) (Ng et al., 2009; Howard et al., 2016). The 'power by the hour' contract, in which an airplane engine manufacturer charges an airline 'by flying hour' for guaranteeing the availability and reliability of their engines, is a good example. Thus, 'power by the hour' is not only a product and service contract bundle (product-service system or solution) or an engine-plus-maintenance leasing agreement (substitution service or subscription) but also a full performance guarantee, where the engine manufacturer incurs penalties in the event that the outcome or result does not meet the target.

As a manufacturer embarks on a trajectory to embrace services alongside its product portfolio or even replace the two by providing outcomes, the change in market strategy may trigger changes in the components of the business model (Demil and Lecoq, 2010; Johnson et al., 2008). The business model represents the design of the activity system, which consists of organizational activities that must be executed in order for the new service to be delivered (Zott and Amit, 2010). Several authors have recognized that service orientation triggers changes across the focal firms' business model (Paula et al., 2013; Reim et al., 2015).

In particular, Bustinza et al. (2013) identify that the servitizing firm shifts from transactional to relational engagement with the other firms involved in the activity system. Indeed, this may mean that a servitizing firm adopts a business model that is closely intertwined with that of a customer. At the same time, Vendrell-Herrero et al. (2017) warn about more frequent appearance of service intermediaries, a specialized service firms that offer wide range of services and position themselves between servitizing firm and its customer. Appearance of an intermediary may affect this relational engagement and warrant a business model that accounts for the interactions with them (the intermediary) as well (Burton et al., 2016). Similarly, Forkmann et al. (2017b) demonstrated how servitization decoupled the relationship between the focal firm and its customers and, on the other hand, coupled between the distributors and customers.

Furthermore, scholars have begun to engage in discussion about capability configuration for servitization (Raddats et al., 2015; Rönnberg Sjödin et al., 2016; Sousa and da Silveira, 2017; Story et al., 2017). Gebauer et al. (2013) argue that manufacturing firms will not be able to master all the required capabilities internally and, therefore, should instead rely on suppliers from various types of service network to execute activities where the manufacturer lacks capability. Finally, Paiola et al. (2013) point out that, besides the options of executing activities internally and externally, there is also an option to execute activities in collaboration with a partner firm, which they refer to as a mixed-capability development. In a nutshell, embracing service and, in particular outcome-based strategies, forces firms to rethink the way they create value for customers but also the way they do their business (Desyllas and Sako, 2013; Hacklin et al., 2017; Priem et al., 2017).

\subsection{Business model changes}

Independently from the service market strategy, business model change has received increasing attention in management research over the last 15 years (Foss and Saebi, 2017; Massa et al., 2017). Setting out to understand the theoretical foundations of value creation in an ebusiness, Amit and Zott (2001) observed that a firm's decision on what products and services to deliver to the customer, which represents the basis of its market strategy, is distinct from its decision on how to deliver those products and services. They coined the business model as a crucial value-creation construct that explains how firms deliver value, which they defined as 'the activity system design'. Furthermore, novel design of the activity systems, which represents business model innovation, emerged as a prominent research area in its own right (Amit and Zott, 2012; Hacklin et al., 2017; Sanchez and Ricart, 2010; Zott and Amit, 2010).

One of the changes that has received considerable attention is the 
shift to the open business model (Chesbrough, 2006; Chesbrough, 2007; Saebi and Foss, 2015). Zott and Amit (2010) argue that an activity system may exceed the boundaries of one firm and grow to represent a system of interdependent activities that transcends the firm's boundaries and spans the ecosystem of firms interconnected by virtue of their value-creation functions. The shift to an open business model represents a redesign of the activity system, involving more of these external firms in the execution of selected activities.

Manufacturers are increasingly adopting open business models as they integrate consumers and other external parties into value creation and value capture (Randhawa et al., 2016; West and Bogers, 2014; Kortmann and Piller, 2016). Opening up a business model is often justified by improving profitability through saving costs by co-developing (von Hippel and von Krogh, 2003) and/or capturing value from complementary resources (Alexy et al., 2017). Furthermore, research demonstrates that open business models allow firms to leverage the capabilities of their ecosystem partners to achieve greater innovativeness as well as effectiveness and efficiency (Chesbrough, 2012; Gianiodis et al., 2014). Strategic openness may also allow firms to reduces uncertainty and facilitates coordination in delivering complex value proposition (Dattée et al., 2017). For instance, some firms choose to establish a dynamic control over different stakeholders, while relying on them to provide products and services to each other (Dattée et al., 2017; Gawer, 2014; Gawer and Cusumano, 2002).

\subsection{Interplay of service market strategy and open business models}

The choice of the business model, therefore, represents an important factor in the successful implementation of the market strategy. Besides the interplay between business model and market strategy (how they decide to tackle customer needs) (Zott and Amit, 2008), scholars have studied the interplay between business model and competitive strategy (positioning vis-à-vis competitors) (Casadesus-Masanell and Ricart, 2010; Teece, 2010) and business model and technology strategy (which technologies they decide to focus on) (Baden-Fuller and Haefliger, 2013; Chesbrough, 2010; Gambardella and McGahan, 2010). In the case of technology strategy, it has been widely acknowledge by now that technology breakthroughs is not sufficient, and new business models that support their commercialization are needed in order to exploit business opportunities (Chesbrough and Rosenbloom, 2002; Tongur and Engwall, 2014; Velu, 2015; Willemstein et al., 2007).

Similar to technology strategy, service market strategy represents an important complement to the business model change since it triggers a major change in value creation and value capture (Chesbrough, 2011; Kortmann and Piller, 2016; Randhawa et al., 2016). For instance, Witell and Löfgren (2013) acknowledged the importance of the change in business model by unpacking the effect that the change from servicesfor-free (where services are a product support and promotion tool) to services-for-fee (where services represent a business in their own right) market approach has on the business model design. However, while these represent notable contributions that shed light on the importance of the interplay between the two value-creation constructs, it is yet to be uncovered how this interplay influences value creation for the manufacturer or software provider. Indeed, it is already known that market strategy and business model change carry implications for value creation independently (Sosna et al., 2010; Chesbrough, 2010; Sinfield et al., 2012; Hienerth et al., 2012; Martins et al., 2015). It has also been established that the interplay between the two is important and determines the success of the company (Teece, 2010; Zott and Amit, 2010). Yet, very little is known about how the two interact or become coordinated in the endeavor to deliver value. This represents a pertinent question in the case of service - and particularly outcome - strategies, given that the shift to highly advanced services is coupled with fundamental redesign of the underpinning business model (Forkmann et al., 2017b; Visnjic et al., 2017). Thus, this study has centered on the question: 'How do market strategy change and business model change interact in response to a shift into services and outcomes, and how does this interplay affect value creation?'

\section{Methodology}

\subsection{Research design}

The nature of the research question prompted a thorough investigation of changes in the market strategy and business model, their independent implications for value creation as well as their interdependency. The case study methodology was chosen to allow us to collect rich observations on complex relational processes (Eisenhardt, 1989; Eisenhardt and Graebner, 2007). Moreover, we opted for an inductive multiple case study design (Yin, 1994).

As suggested by Glaser and Strauss (1967), theoretical sampling was chosen, selecting cases would make it possible to illuminate the relationship between constructs of the market strategy and the business model (Suddaby, 2006; Eisenhardt and Graebner, 2007). In this theoretical sampling, it was decided to identify firms that already had experience providing the most advanced forms of services and outcomes. This facilitated mapping out the entire evolution of the service portfolio that preceded this advanced stage as well as the corresponding business model changes.

The sampling was approached by first identifying the sectors flagged by the academic literature and academic experts where servitization was particularly pronounced. Review of the academic literature and discussions with academic experts identified six sectors: (defense and construction) equipment manufacturing, construction, utility, rail transportation, IT, and consulting (Davies et al., 2007; Neely, 2008, 2014; Josephson et al., 2016).

Second, firms were selected from within these sectors by relying on practitioner-oriented publications, trade press and industry experts. The primary focus of this research was to make a selection from sectors with different degrees of concentration in the customer base, knowing that sectors with higher concentrations of customer base are better placed to deliver customized solutions and outcomes (Davies et al., 2006). The sample included firms such as defense and transportation solution providers that tended to have one or two customers, as well as consulting and IT providers that had hundreds of customers. Overall, six firms operated in a single-customer ecosystem, two operated in ecosystems with multiple similar customers dominant within a geographic area and, finally, four firms operated across different ecosystems with multiple customers.

The six sectors varied in aspects other than the aforementioned concentration in the customer base. For instance, IT hardware, software and services have shorter product lifecycles than the other sectors, particularly rail transportation and the utility sector (Cusumano et al., 2015). Furthermore, the aerospace and defense sector has a highly concentrated user customer base (Ng et al., 2009; Batista et al., 2016), particularly compared to equipment manufacturing and IT hardware, software and services (Oliva and Kallenberg, 2003; Suarez et al., 2013; Visnjic Kastalli et al., 2013).

The final selection included 12 firms, from the 6 sectors chosen (see Table 1 for SIC codes): 3 equipment and solution providers ( 2 from aerospace and defense, 1 from construction), 2 rail transportation providers, 2 utility equipment and services providers, 2 construction and maintenance services providers, 2 IT hardware (computer), software and consulting services providers, and 1 consulting services and solutions provider. While 11 firms were initially product providers that shifted into services and outcomes, the last firm on the list was in fact a service provider that shifted into advanced services and outcomes. This firm was treated as a comparative baseline in the data analysis, in order to identify potential differences in patterns between the 11 product 'natives' and this service 'native'. The results showed, however, that the patterns closely resembled those of the two IT hardware and software providers that shifted to consulting services and solutions. 
Table 1

Company information table (latest available).

\begin{tabular}{|c|c|c|c|c|c|}
\hline & Sector & SIC Code & Clients (range) & Employees (range) & Revenues (million \$) \\
\hline $\mathrm{BAB}$ & Aerospace and Defence Equipment and Solution Providers & 3721 & $<10$ & $1000-10.000$ & $<1000 \mathrm{~m}$ \\
\hline ВOB & Train and Train Manufacturer & 4011 & $<10$ & $1000-10.000$ & $1000-10.000 \mathrm{~m}$ \\
\hline CAR & Construction Equipment, Services and Consulting & 3531 & $10-100$ & $1000-10.000$ & $<1000 \mathrm{~m}$ \\
\hline HIC & Train and Train Manufacturer & 4011 & $<10$ & $<1000$ & $<1000 \mathrm{~m}$ \\
\hline IBA & IT Hardware, Software and Consulting Services & 7371 & $>1000$ & $>10.000$ & $1000-10.000 \mathrm{~m}$ \\
\hline MAG & Construction and Maintenance Services & 3531 & $10-100$ & $1000-10.000$ & $1000-10.000 \mathrm{~m}$ \\
\hline NIS & Consulting Services and Solutions & 8748 & $10-100$ & $<1000$ & $<1000 \mathrm{~m}$ \\
\hline ROR & Aerospace and Defence Equipment and Solution Providers & 3721 & $10-100$ & $>10.000$ & $1000-10.000 \mathrm{~m}$ \\
\hline STR & Utility Equipment and Services (Water) & 5084 & $>1000$ & $1000-10.000$ & $1000-10.000 \mathrm{~m}$ \\
\hline SMS & Utility Equipment and Services (Energy) & 5084 & $10-100$ & $>10.000$ & N/A \\
\hline SWO & IT Hardware, Software and Consulting Services & 7371 & $<10$ & $<1000$ & $<1000 \mathrm{~m}$ \\
\hline VIN & Construction and Maintenance Services & 3531 & $100-1000$ & $1000-10.000$ & $1000-10.000 \mathrm{~m}$ \\
\hline
\end{tabular}

Choosing on average two firms from each sector helped the process of isolating patterns that were consistent across firms and across sectors. More specifically, a 2-step analysis was performed where, first of all, firms within the same sector were compared, isolating patterns for each sector, and then the patterns across the sectors were compared. This helped to strengthen replication logic and increase construct validity (Yin, 1994). Pair-wise comparison was made within a sector resulting in sector-specific conclusions, which could then be followed by cross-sector comparison producing generalized insights. The sample of 12 cases was large enough to extract theoretical insights from the data (Glaser and Strauss, 1967; Eisenhardt, 1989). This sample also facilitated the detection of patterns that are consistent across the large variety of sectors (Edmondson and Mcmanus, 2007). Table 1 provides an overview of the cases.

\subsection{Data collection}

For each of the case firms, interviews were conducted with over 42 informants lasting approximately $90 \mathrm{~min}$ each. Informants came from the ranks of top management (e.g. Chief Executive Officer, Chief Information Officer, managing consultant, business lead). The right profile and seniority of the respondents took priority over the number of respondents within the firm. This research focused primarily on interviewing top management because of the all-encompassing and strategic nature of the topic and the questions we sought to obtain. This seemed sufficient to obtain a coherent picture of the firm's product and service portfolio and its business model.

The interview structure rested on the core constructs of the service market strategy and business model research outlined earlier (Kvale, 1996). Firstly, respondents were asked to outline their market strategy, explain how it had evolved, and describe what were the intended and unintended (desirable and undesirable) implications of the strategic change on value creation. Then, they were asked how the business model had changed, and what were the implications of this change. Probing further, questions were posed about the interdependencies between market strategy and business model change they had described, as well as the shared implications for value creation.

While focusing on the constructs derived from the literature, more general labels were used to describe them. For instance, the primary researcher sought to obtain a full picture of the content, structure and governance of the firm's business model (Zott and Amit, 2010) by asking 'who provides which activity and how is this provision organized?'. The primary researcher then asked explicit questions such as 'what is the firm's market strategy, and how did it change over the last period?', 'what is your business model, and how did it change over the last period?', 'how and why did you involve partners in these activities?' 'how do you create value within your market strategy and business model?', and 'how do you capture that value?'.

\subsection{Data analysis}

Interviews were recorded and then transcribed, while background data were collected from secondary sources in parallel (Yin, 1994). Transcripts were first coded with respect to their fit with the broad categories defined in the literature (market strategy and business model/activity system design)(Corbin and Strauss, 1990). During the second coding, new subcategories were allowed to emerge with particular emphasis on the change (Corbin and Strauss, 1990; Birks and Mills, 2011). For market strategy change, important changes in scope, time and outcome were recognized. Similarly, for business model change, three subcategories of activities that were the most affected by the shift to an outcome business model were distilled: these were labelled internal, supplier, and partner. After analyzing the business models of each individual firm independently, two researchers instituted an independent cross-firm analysis. The resulting insights were compared across the categories and sub-categories, with the aim of identifying patterns and arranging them in a coherent 'story line' that explained the firm's value creation change. The researchers then compared the resulting insights to obtain a coherent narrative. Differences in the analysis were resolved by re-examining data from the interviews.

In an effort to validate understanding of the characteristics of individual firms' business models, firm representatives were first invited to workshops where the analysis of their business model was presented and/or informants were sent their business model profiles. Second, the results of the cross-firm analysis were shared with diverse group of academics and practitioners, including the informants from the casestudy organizations. All comments presented on individual-case or cross-firm analysis were accepted and incorporated into the overall analysis. Table 2 summarizes efforts related to the data collection, analysis and validation.

\section{Findings and propositions}

Insights offered by respondents easily lend themselves to being categorized into three broad areas: the shift towards service and outcomebased market strategy and the corresponding implications for value creation; the shift towards open business model and the corresponding implications for value creation; the interplay of the two and the implications of this interplay for value creation. In the Tables below, supportive findings from each of the 12 cases are presented: Table 3 summarizes the changes that firms made as they shifted from a product into a service and outcome market strategy and from a 'closed' towards a more open business model. Tables A1, A2, respectively, offer quotations that link these changes to value creation and increase in risks and uncertainties. In the subsequent section, we elaborate on these findings are explained and a number of interlinked observations, which are then summarized in a conceptual framework, are derived. 
Table 2

Data collection, analysis and validation.

\begin{tabular}{|c|c|c|c|}
\hline Code & Interviewees & Observations & $\begin{array}{l}\text { Workshop /conference } \\
\text { attended }\end{array}$ \\
\hline $\mathrm{BAB}$ & $\begin{array}{l}\text { Business Lead, Service Design Engineer Capability Manager, Head of Capability Development, Head of } \\
\text { Systems Engineering, Head of Strategy and Planning, Head of Programme Governance, Head of Service } \\
\text { Unit }\end{array}$ & $\begin{array}{l}\text { Several company visits, } \\
\text { workshops, speeches }\end{array}$ & YES \\
\hline BOB & $\begin{array}{l}\text { Director, Predictive Asset Management, Business Development Responsible, Service Contract Manager, } \\
\text { Monitoring Specialist }\end{array}$ & A company visit & YES \\
\hline CAR & Manager Supply Chain Solutions, Vice President Business Development & $\begin{array}{l}\text { A company visit, speeches, } \\
\text { workshops }\end{array}$ & YES \\
\hline HIC & Maintenance Delivery Manager, Head of Maintenance Delivery, Chairman and CEO & Two company visits & YES \\
\hline IBA & $\begin{array}{l}\text { Managing Partner and General Manager, Consulting Services Leader, Executive Partner (2), Client and } \\
\text { Programme Executive, Banking and Financial Markets Executive Architect, Senior Managing } \\
\text { Consultant }\end{array}$ & $\begin{array}{l}\text { Several company visits, } \\
\text { workshops, speeches }\end{array}$ & YES \\
\hline MAG & Director of Information Systems - Chief Information officer (CIO) & A company visit & NO \\
\hline NIS & CEO Europe, Vice President UK & A company visit & YES \\
\hline ROR & Head of Business Analysis, President of Services Business, Head of Services Research and Development & Speeches & YES \\
\hline STR & Director, Strategy and Regulation (CEO), Chief Information officer (CIO) & A company visit & NO \\
\hline SMS & Director and the CEO & A company visit & NO \\
\hline SWO & Director, CEO, Executive Partner & A company visit, speech & YES \\
\hline VIN & Commercial Director & - & YES \\
\hline
\end{tabular}

* For each firm in the sample the case histories were supplemented by internal documentation and archival records. In addition, the reports were mailed back for validation to the firm representatives.

\subsection{Market strategy shift}

Representatives of each of the 12 case firms reported that they added services and then went on to make the transition to outcomes with the objective of maximizing coverage of customers' functional needs. For example, a significant 'step' in the expansion of the market strategy would be for a defense system provider to expand its portfolio from delivery of a standardized military aircraft to a 'guarantee of an air combat capability with certain technical specifications over 20 years'. Subsequently, this could be expanded with the defense solution

Table 3

Market Strategy Change and Business Model Change summaries.

\section{Market strategy change}

BAB: Scope- From spare parts delivery to spares inventory management. Time- From adhoc supply of spares to a multi-year contract (up to 5 years). Outcome- Now guaranteeing spares availability for target cost (price $/ \mathrm{km}$ of vehicle use).

вов: Scope- From train sales to through-life train asset management service portfolio. Time- From ad-hoc maintenance service provision to multi- year contracts. OutcomeNow penalty clauses and revenue share incentives (e.g. energy efficiency).

CAR: Scope- From warehousing to 24 supply chain (SC) related services. Time- From commodity services of 1-2 years, to customized 5-year contracts. OutcomeContracts $\mathrm{w} /$ guaranteed availability of inventory including maintenance, repair and operations (MRO) processes.

HIC: Scope- From trains to train solutions (refurbishment, full rebuild and cleaning). Time- From ad hoc to $7-9$ years and finally $27(7+20)$ years. Outcome- Charging for usage guaranteeing availability, reliability and cleanliness.

IBA: Scope- From hardware to services and integrated solutions. Time- Post-merger integration IT projects last between 36 and 60 months. Outcome- A structured process to assess the possibility and the level of guarantee.

MAG: Scope- From blue-collar services (road repair) to all city support services. TimeFrom one-off projects to 5- year contracts and above. Outcome- Revenue-sharing agreements based on cost targets

NIS: Scope- From connecting clients to research community to helping in problem definition. Time- Developing into long-term relationships where NIS works closely with clients. Outcome- Vouching with reputation that found solution does not exist elsewhere.

ROR: Scope- From selling engines to selling engine capacity. Time- From ad-hoc supply of spares to long-term contracting for capability. Outcome- Guaranteeing engine performance, in terms of availability and reliability.

STR: Scope- From clean water to all-water and 'door-to-door' solutions. Time- Working under 20 -year rolling contracts. Outcome- Delivery of service is measured by 20 KPIs. (e.g. leakages, quality).

SMS: Scope- From energy data reading to smart meter installations and data analytics. Time- Starts with pilots (install one or two smart meters), to get long-term renewal contracts (3 years and more). Outcome- Paid for quality data only; not all data collected

SWO: Scope- A set of 8 interrelated IT support services to citizens. Time- The partnership, which is set to run for an initial period of 10 years, began in 2007. Outcome- Provider makes $100 \%$ of the profits and covers $100 \%$ of the losses.

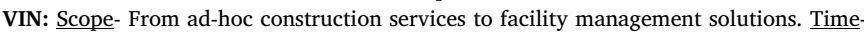
From ad-hoc services to $3-5$ years contracts to $25-40$ years contracts. OutcomeContracts for facility service availability with response time penalties.
Business model change

Internal- New activities to manage the inventory, investments in inventory IT systems. Suppliers- Increase in complexity of the supply chain- number of suppliers. PartnersStarted partnering for delivery of spares for partner's vehicles.

Internal-New data diagnostics experts and systems service business model adoption. Suppliers-New technical support and spares supply contracts w/ suppliers. PartnersStarted partnering for provision of technical support and spare supplies. Internal-Developed internal knowledge on inventory management. SuppliersSubcontracting the transportation services. Partners-Partnering $\mathrm{w} /$ consulting and software firm to develop SC software

Internal-Hired with well-trained and experienced service staff that do a range of jobs. $\underline{\text { Suppliers-Extended contracts with their suppliers into spares supply. Partners- }}$ Partnering with depot developers to finance train ownership. Internal-Came up with structured engineering process to assess guarantee offerings.

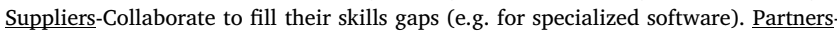
Global research network (3500 pure researchers)

Internal-Substantial expansion through acquisition of support-service providers. Suppliers-MAG relies on the supply network of small local service providers. PartnersPartnering with IT provider to generate data for all city support services Internal-NIS hired PhDs in diverse fields to translate and generalize problems. Partners-NIS nurtures network of 2 million researchers

Internal-Monitoring room to track engines in real-time on civil aircraft. SuppliersExtensive product and technology supply chain. Partners-Integrated solution delivery in partnership $\mathrm{w} /$ other service firms

Internal-Investing in data analytics using social media for customer support. Suppliers-Outsourcing to third parties (e.g. private drains and sewage leakage). Partners-Partners with engineering firms for designing and building water wells. Internal-Invested in data analytics competencies. Suppliers-Relies on workforce solution providers for management of field workers. Partners-Partnering with offshore wind farms solution providers.

Internal-Created entirely new organization with novel organization- a JV with clients. Suppliers-Each of the partners brought its own suppliers

Partners-Services partly provided by the three JV partners- city councils. Internal-Consolidated scattered service outlets in a consolidated service chain.

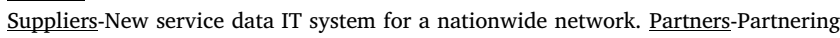
with an IT company to ensure full integration with the client's system. 
provider taking responsibility for design of the aircraft incorporating certain specifications, for the availability of the system through its working life, and for all related services (e.g. maintenance, monitoring) that are necessary to vouch for such a capability.

The analysis of the market strategy changes confirmed that 11 manufacturers and software providers were increasingly shifting towards services and outcomes, and the one consulting services provider was adding additional services and shifting into outcomes as well. This comes as no surprise given that this was sampling criterion. However, by analyzing the service portfolio expansion of case-study firms, we managed to unpack the overall shift and isolate three separate phases of expansion towards the outcome-based market strategy. First, the firms expanded their portfolios by expanding the scope of the services or adding new services. For example, a construction equipment provider (CAR) began by offering basic warehousing services and then gradually expanded the value proposition to cover the complete spectrum of logistic services, including procurement and transportation. On many occasions, these 'new services' had been previously executed by the customer. The project manager at the construction equipment manufacturer explained, "We start with the simple services. Let's say warehouse management, plus transportation, and people. And after having seen what we do, how we work, the level of quality we deliver, the customer makes some more enquiries for new, more complex services, like customer support, inventory management, packaging services."

Second, the firms extended the time frame of the service, vouching to provide the required service over an extended period. Here, the services changed from the transactional to the relational; once the longterm contract has been signed, two members of the organizations would invest more time in building relationships with each other and working more collaboratively. For example, an equipment manufacturer shifted from 'on demand' maintenance of trains, delivered upon the request of the customer ('when customer calls') to a regular maintenance contract spanning several years with a preset maintenance schedule. A senior executive explained, "Management spotted the opportunity to move from a project-based business into a more long-term relationship with customers. The customers got one large contractor (referring to the firm under study). Having (only) one provider supplying the whole range of services gives them office economies of scale."

Third, the firms shifted from providing services as activities or processes to guaranteeing the outcome of those services or a performance corresponding to the activity executed. In this example, a supply chain consultancy guaranteed a certain level of inventory combined with an assurance covering the availability of the stock rather than charging for hours spent on warehouse management and transportation service.

Observation 1a. Firms extend their market strategy into services and, finally, outcomes using three different phases: first, expansion of the scope of services, second, extension of the service time frame, and third, adding performance guarantees related to their product-service portfolio.

Besides revealing the phases in the transition from products to services, analysis uncovered the motivations associated with this shift.

First, by expanding the scope of the service portfolio, firms assume the responsibility of coordinating different product and service activities on behalf of their customers. More specifically, they begin by managing the multitude of services that are interdependent and tangential to customers' own core businesses, where they can be more cost effective than the customer. For example, several years after the UK rail privatization, train manufacturers took over train maintenance from the train operators - after the latter recognized the link between manufacturing and maintenance.

Second, with a long-term contract, the firm can improve the quality of the service. More specifically, securing a long-term contract that will generate revenues over a number of years means that the firm can justify larger upfront investments in the assets or systems that would improve the quality of service delivery. For the equipment manufacturers involved in supply-chain service provision, securing a longterm contract to manage the supply chain on behalf of the customer justified investments in the design of a specialized IT system that would offer a better supply chain service. Conversely, if there would be no long-term contract and consequent uncertainty in future revenues, the firm would not make this investment. Similarly, a project manager at one of the rail transportation firms explained, "If we extend contracts to 15, 20 year contracts... it works well for us because we can invest. So, on a 7-year contract, we can't really invest and we also have the incentive conflict, because the way you optimized on the 5-7 years would be different than for 20 years."

Finally, by guaranteeing the results that the customer is seeking, firms take on the risks and uncertainties formerly shouldered by the customer. From the firm's perspective, this creates value by securing long-term revenue streams. As one project manager illustrated, "it's pretty much delivering performance... the majority of our contracts tend to be, what we call line-based (recurring) fees, guaranteed cutoffs, guaranteed availability, guaranteed inventory returns, whereby in fact we take the risk. And obviously, with risk comes reward". In return for reduced uncertainties, guaranteeing performance leads to growth in revenues for the firm.

Observation 1b. Each of the phases associated with the shift into services creates value for the company in a specific way: scope expansion reduces complexity and increases efficiency, time frame extension increases revenue security and allows for upfront investments, performance guarantees reduce customer uncertainties and secure growth for the manufacturing firm.

At the same time, the firm becomes exposed to certain risks and uncertainties. To start with, the firm espouses the operational risk associated with new service activities.

Second, a consequence of signing a long-term contract creates what we refer to as 'dynamic uncertainties', or the uncertainties associated with changing environmental conditions. This is especially true if leasing of equipment is associated with the long-term contract. For example, train manufacturers are beginning to offer 'trains as a service' charged on a 'per day' basis in a contract that spans years and even decades instead of selling the train and offering on-demand maintenance. This increase in the time frame from on-demand to long-term contract induces (at least) two sources of uncertainties related to changing environmental conditions: the risk of volatility in financial markets and the changing interest rate. A manager illustrated the multitude of environmental factors that can change: "You make a commitment. And the trouble is, a lot of that is not that easy. Things (referring to unexpected costs) come along that you don't expect. Things change. Other people's margins change. They (referring to partners and suppliers) put their prices up. And, you have to then redistribute your cost profile."

When firms make the transition from delivering a service as a 'process' (e.g. delivering warehousing activities on demand or in a longterm contract) to guaranteeing a service outcome (e.g. guaranteeing reduced inventory levels), they espouse performance risks and uncertainties. This risks and uncertainties stem from the inability to foresee all the factors that may prevent the firm from meeting performance targets and incurring penalties associated with the failure to do so. For example, at the onset of service provision, one of the train manufacturers that started offering train services faced thousands of pounds in penalties on a daily basis due to its failure to make available the agreed number of trains each day. Similarly, the IT hardware and service provider (SWO) that embarked on a joint venture with its customers faced losses of $£ 18$ million in a single year, due to its inability to deliver the services to the expected level of efficiency. For instance, Head of Maintenance Delivery at HIC explained, "We had to fix the price of the contract before we actually started the deal, so it meant we had to sort of take a punt on the labor rates based on our experience." 
Observation 1c. The shift into services and outcomes creates different types of risks and uncertainties: scope expansion introduces operational uncertainties (uncertainties of being able to perform a new service activity), time frame expansion introduces dynamic uncertainties (uncertainties associated with changing environmental conditions) and performance guarantees introduce performance uncertainties (uncertainties of being able to meet product/service performance criteria).

\subsection{Business model shift}

Besides changing their market strategies, the firms also reported changes in their business models. As they increased the scope of the service portfolio, the range of activities needed to be performed began to increase as well. When these activities were closely related to the activities they already performed and where they had substantial competencies or the potential to develop certain competencies in the future, firms made a decision to execute these activities on their own. For example, an ICT hardware and consultancy services provider continued to produce standardized products - such as mainframes - because they were necessary 'entry tickets' to provide through-life support and consulting. They also started to design a business process model and develop an appropriate ICT architecture for their customers, as this was closely related to their existing activities.

As the shift in market strategy progressed into more encompassing and longer services, service activities began to appear that fulfilled the contract requirement but were unattractive from the financial standpoint or unrelated to the firm's competencies. This prompted firms to open up their business models. First, having to deal with financially unattractive 'simple'service activities led firms to outsource these activities to suppliers who were prepared to execute them on behalf of the firm for a competitive price. For example, a facility maintenance provider outsourced cleaning services, a logistics service provider outsourced transportation, a train manufacturer outsourced painting, and a logistics provider outsourced transportation.

Second, the time frame expansion and the performance guarantees increasingly triggered the need for more complex service activities that required specialized competencies or assets. These services were far removed from the firm's core activities and competencies and, therefore, required collaboration with specialized partners. For example, a water utility firm increasingly partnered with construction expert firms on the design and delivery of complex water containers, while an equipment manufacturer with supply-chain consulting solutions partnered with software designers to develop state-of-the-art software for supply chains and logistics. The collaborations with partners tended to be much more complex than outsourcing agreements with suppliers and, as the number of partnerships increased, so did the complexity.

Observation 2a. Firms are extending their activity systems with additional activities using three different modes: first, internal delivery (when the activities are close to their competencies), second, supplier outsourcing (when activities can be performed more efficiently externally) and, third, partner collaboration (when specialized external competencies or assets are necessary).

While extending its service portfolio assures growth through creating value for customers, extending the activity system provides the opportunity for efficiency and innovation. To start with, internal execution of new activities related to the firm's competence base helps to achieve economies of scope internally. More specifically, as the volume of similar activities grows, the firm can cross-leverage their fixed assets (e.g. IT infrastructure) on a higher volume of activities.

For the service activities that require very few competencies or commoditized services, providers achieved lower cost bases by outsourcing the activities to the cheapest suppliers. Stated differently, outsourcing these service activities to the (commoditized) sub-suppliers ensures that the service activities are provided most cost effectively. Explaining how efficiency of the activity system is achieved, a senior executive commented, "We manage suppliers. We manage the in-boundary fix and flow and then the outbound flow to the customers".

Further, in the case of some of the sophisticated new service activities, firms were prompted to reach out to partners in order to leverage their competencies. Relying on collaborators with complementary skills and competencies allowed the firm to generate complementarities and, in particular, to combine their respective expertise to innovate. Explaining how they managed to design a new IT system for supply chain management, a senior manager responsible for the supply chain consulting services commented, "We've set up an alliance some time ago to work with SAP on the latest aftermarket software. We created a live SAP module for the next generation of service part management."

Observation 2b. Each of the modes associated with the activity system expansion creates value for the firm in a specific way: internal delivery of related activities realizes economies of scope, supplier-led execution of commoditized activities increases efficiency, and partner-led execution of the sophisticated yet unrelated activities lead to complementarities and innovation.

At the same time, activity system redesign exposes several uncertainties and risks. As mentioned earlier, when a firm starts to perform new activities (even if related to their capabilities), they become exposed to operational risks and uncertainties simply because they are novel. An ROR manager explained, "some of these other more innovative ideas are a bit riskier because they've not been tried before and I can't quite imagine it, because it's new and different."

Besides these internal uncertainties, informants also reported uncertainties related to opening up the activity system to suppliers and partners, including the customers themselves. These uncertainties were often rooted in difficulties securing adequate interface standards (e.g. long-term contracts) and in the resulting lack of accountability of suppliers. One of the senior executives described a situation where it had taken accountability for the performance of the train over a long period of time, but it struggled to convince its suppliers to guarantee provision of spare parts over the same period of time. In an arrangement where the train was sold as opposed to leased with a performance contract, the customer would shoulder the uncertainties of not being able to procure spare parts.

New uncertainties also appeared in the collaboration with partners. In this context, they were often related to the unforeseeable challenges in cross-boundary coordination and changes in incentives. Furthermore, in the advanced contracts with performance guarantees, customers often assumed the role of the partner and, thus, the expansion of the activity system would change the incentives of the customer himself. For example, once the long-term performance contract was signed and the train manufacturer assumed responsibility for throughlife provision of a functioning train, the key employees of the customer - train operators - were less concerned about the wear and tear of the train and began to drive more recklessly, leading to more frequent train malfunction. Besides uncertainties associated with the incentives and coordination, in the case of the partners, analysis also revealed uncertainties associated with innovation. Stated differently, coordination and incentives were more uncertain because they also carried the inherent uncertainties of (joint) delivery of a novel set of activities.

Observation 2c. The expansion of the activity system, following the shift into services and outcomes, creates different types of uncertainties: internal uncertainties (uncertainties associated with the ability to execute a new service activity internally), supplier uncertainties (uncertainties associated with supplier incentives and coordination) and partner uncertainty (uncertainty of partner incentives and coordination related to the novel activities). 


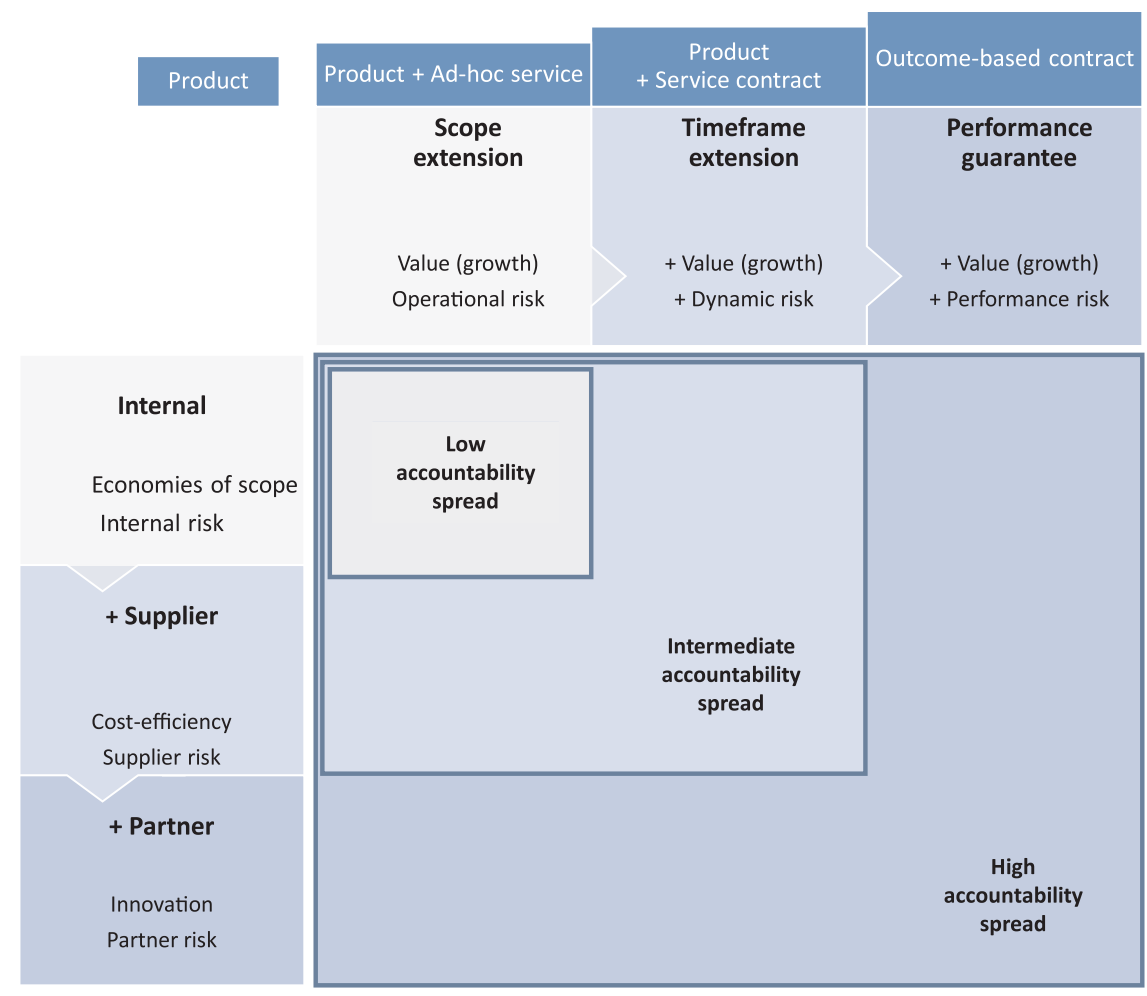

Fig. 1. Interplay of Service Market Strategy and Open Business Models.

\subsection{Relationship between market strategy shift and business model shift}

Fig. 1 below presents the conceptual framework and summarizes propositions related to the shift to a service/outcome market strategy, a shift to an open business model, and their relationship. More specifically, Fig. 1 portrays the phases of the service market strategy shift (horizontal axis) and the corresponding modes of opening up the business model (vertical axis).

As illustrated by the horizontal axis, the shift to service market strategy consists of three different phases: extension in the scope of services, extension in time frame and inclusion of performance guarantees. In the aforementioned example, the manufacturer of train vehicles started with the (on-demand) delivery of the maintenance service, then signed a 7-year contract to provide that maintenance service, and finally evolved into a performance-based contract spanning more than 20 years and guaranteeing availability, reliability and cleanliness of the fleet of trains.

Not only are these phases sequential, but this research paper also suggests that the performance guarantee almost always encompasses time-frame extension and scope expansion and that the time-frame extension almost always encompasses scope expansion. For instance, a firm that commits to a performance-based contract guaranteeing the availability of equipment (performance guarantee) very often has to be prepared to sign this contract over a certain period of time (time-frame extension) and to guarantee availability, i.e. to accept responsibility for maintenance of the equipment (scope expansion).

Observation 3a. Three modes of the market strategy shift/service portfolio expansion are sequential and interrelated. Performance guarantees encompass time-frame extension and scope expansion, while time-frame extension usually encompasses scope expansion. Manufacturers tend to approach this shift gradually, initially with scope expansion, followed by time-frame extension, and finally with performance guarantees.

As illustrated by the vertical axis, the business model shift/activity system expansion consists of three qualitatively different modes: the addition of internal activities, the addition of activities performed by the supplier, and the addition of activities performed by partners. These three modes of the business model shift are not necessarily interrelated with each other but are triggered by the phases of market strategy shift/ service portfolio expansion. More specifically, service scope expansion leads to internal activities, time-frame extension likely encompasses supplier activities, and performance guarantees often lead to the inclusion of partner activities.

A good example of the interrelatedness between service expansion modes and activity system expansion modes comes from the supply chain service and consulting, performed by one of case-study firms. The equipment manufacturer started with on-demand delivery of a warehousing service and then went on to procure from time to time several services that were related to supply-chain management, such as warehouse-inventory management. These services were delivered internally, by leveraging existing warehousing used for their own equipment (internal activity). Gradually, they replaced this portfolio of individual services with a long-term service contract for management of the customer's supply chain, including the transportation of inventory directly linked to warehousing. While the supply chain contract included transportation as the responsibility of the firm in this case study, it was not best placed to deliver cost-effective transportation services internally. Thus, it decided to take on the responsibility but to outsource this commoditized service to specialized suppliers (supplier activity). Finally, the case-study firm shifted from a long-term supply chain service contract to a performance-based supply chain service contract, where it guaranteed availability of the inventory to their customers. In order to discharge this responsibility, they partnered with an ERP system provider to design new specialized supply chain management software (partner activity).

Observation 3b. Three modes of the business model shift/activity system expansion are interrelated with the modes of market strategy shift/service portfolio extension. Internal activities are likely to emerge with extension of the scope of services, supplier activities are likely to materialize with time-frame extension and partner activities are likely 
to appear with more complex performance guarantees. In line with the market strategy shift/service portfolio extension, business model shift/ activity system expansion begins with new internal activities and then increasingly 'opens' the activity system by including supplier and partner activities.

As stated earlier, each phase of service portfolio extension brings its own value creation potential (1b) as well as uncertainty and risk (1c). As these phases are sequential (observation 3a), the value creation potential as well as the risks and uncertainties accumulate. In other words, as manufacturers and software providers progress in the provision of additional on-demand services, then on to those services with longer time frames, and finally to performance guarantees during those time frames, they accumulate growth opportunities and secure future revenues. However, in addition to this increase in growth potential, they also accumulate risk and uncertainty, at first operational, then dynamic, and finally performance uncertainty.

At the same time, the effect of each phase of service portfolio expansion on activity system expansion implies that the same 'cumulative effect' occurs with activity system value creation opportunities and uncertainty. More specifically, service scope expansion prompts internal activity expansion; time-frame extension prompts supplier activity expansion, and performance guarantees prompt partner activity expansion. As a result, activity system value creation opportunities (economies of scope, then cost-efficiency, and then innovation) and risks and uncertainties (internal, supplier, partner uncertainty) accumulate as well.

This paper refers to this cumulative increase in value creation potential and uncertainty, on both the market strategy and business model sides, as an accountability spread. This label was chosen because, with service portfolio expansion, a firm increases its accountability to the customer whilst opening up the activity system spreads accountability for the delivery of service activities by its partners and suppliers.

Observation 3c. A market strategy shift to services and the consequent shift to an open business model introduce a cumulative effect in terms of service portfolio value creation and service portfolio risk and uncertainty, coupled with an increase in activity system value creation, and activity system risk and uncertainty. This step-wise expansion in value creation potential and uncertainty is labelled, the accountability spread.

\section{Conclusion and discussion}

The market strategy and business model changes by manufacturing firms and software providers seem to exhibit two concurrent tendencies. On the one hand, firms change their market strategy by expanding the scope of their services, extending the timeline of services and guaranteeing the performance of both product and services. As a consequence, the manufacturer's activity system is enlarged with additional activities that are delivered either internally or through outsourcing to suppliers (if more efficient delivery is needed) or through collaboration with partners (if additional competencies are required). This enlarging and opening up of the business model generates value through economies of scope (internally), through greater cost effectiveness (by commoditized suppliers) and by introducing innovation (through partnerships). Indeed, these two interlinked changes help manufacturers and software providers to create value by growing, and doing so efficiently and effectively. Yet, at the same time, these firms accept greater accountability in terms of customer outcomes and, thus, customer-oriented uncertainties and risks (operational-, dynamic-, and performance-related). This is coupled with relinquishing control over the activity system to suppliers and partners, and accumulating associated risks and uncertainties (internal, supplier and partner uncertainty). This two-fold increase in the potential for value creation and uncertainty is labelled, 'the accountability spread'. It is argued in this paper that a firm embarking upon this journey needs to consider where it wants to place itself in relation to this risk-reward trade-off, and what kinds of capability it possesses that will allow it to materialize the potential for value creation whilst containing the uncertainty. Judicious identification of appropriate levels of accountability spread in combination with management's capacity to actualize value creation potential and to curb uncertainty represent key capabilities in the shift to services.

\subsection{Academic contributions}

This study relates to the literature on servitization and service market strategies, and on business models, in several ways. It contributes to the understanding of the shift to service market strategy by delineating change steps that the firm makes on the level of its portfolio. Indeed, the notion that product-oriented firms add layers of services to their products is not new (Chase, 1981; Vandermerwe and Rada, 1988). However, while the notion of adding services based on different activities (e.g. adding maintenance followed by monitoring activities) is well-established, further steps that take the service market strategy in the direction of outcomes (i.e. timeline extension and then performance guarantee addition) have not been clearly defined. This also makes a contribution to the literature looking at how firms shift to other, more encompassing, closed-loop value chain market strategies (Kortmann and Piller, 2016). Furthermore, while most of the previous literature provides typologies (Kortmann and Piller, 2016; Visnjic et al., 2017), this study offers the process perspective.

This research paper strengthens understanding of service/outcome market strategies by explaining the value creation and capture rationales that prompt firms to shift to service market strategies and consider the value creation/capture that occurs at each step of the shift to services and outcomes (i.e. different types of growth rationale that promote expansion of activities, extension of the timeline, and addition of guarantees). Moreover, while prior literature (Visnjic et al., 2017) has looked at the value-creating rationales underpinning the shift to service and outcome market strategies together with the subsequent shift in the business model, this study unpacks the value-creating implications of the two changes and explore them separately.

This paper contributes to the servitization and open service innovation literatures by advancing another mechanism to explain why and how services, openness and business models are connected (Chesbrough, 2011; Kortmann and Piller, 2016; Saebi and Foss, 2015). Prior literature guided by the seminal contribution of Chesbrough (2011) focuses on the process by which open innovation practices trigger the adoption of a service business model. This is consistent with the assertion of Cusumano et al. (2015) who find that more elaborate innovations require the sale of additional services. This study reveals the opposite relationship to be true as well; findings suggest that the shift to a service market strategy stimulates the shift to an open business model, thereby complementing the findings of Chesbrough (2011) and Cusumano et al. (2015).

Furthermore, recognizing the service market strategy as an antecedent to open business models makes a contribution not only to the open business model literature but also to the broader business model literature. So far, colleagues have focused on technology strategy and other product market strategies as antecedents to business model innovation (Baden-Fuller and Haefliger, 2013; Chesbrough, 2010; Chesbrough and Rosenbloom, 2002; Massa et al., 2017; Zott and Amit, 2008). Furthermore, revealing the service (outcome) market strategy as another antecedent to the open business model offers a lateral contribution to this line of research (c.f. Appleyard and Chesbrough, 2017).

Besides highlighting the antecedence from service strategy to open business model, the mechanisms and value creation/capture rationales by which this happens are unpacked. As with service market strategy, the steps leading to the shift to the open business model and on to the value creation/capture rationales are delineated. Specifically, the study 
helps to explain when and how servitizing firms execute activities internally, and engage with suppliers or partners. In doing so, it offers a distinction between supplier relationships, which are mostly driven by efficiency rationales, and partner relationships, which are mostly driven by effectiveness, competence combination and innovation rationales (Kortmann and Piller, 2016). Consequently, this study may also add to the value migration concept as it distills activities related to shift in value-creating forces (Alexy et al., 2017; Hacklin et al., 2017; Slywotzky, 1996).

This research paper contributes to the literature on business models by using a process perspective to explore the steps involved in business model change. Moreover, for each step in business model change, antecedent change in the service market strategy are identified. This interdependence and co-evolution of the service market strategy change and the business model change is very frequently observed in the manufacturing and software sectors, but the process by which it unfolds has been largely overlooked by scholars (Forkmann et al., 2017b; Massa et al., 2017; Priem et al., 2017). Indeed, outlining the process of interdependence supports the efforts of scholars who have separated the market strategy and the business model, and noted their interdependence, but have not yet mapped the process by which this unfolds (Zott and Amit, 2007, 2008).

This study emphasizes that, in order to understand how the interplay of (service) market strategy and business model changes affects value creation (Casadesus-Masanell and Ricart, 2010; Teece, 2010), risk and uncertainty are crucial parameters to consider together with sources of value creation (Reim et al., 2016). Servitization literature has begun to recognize accountability as a business model driver (Visnjic et al., 2017). While Visnjic et al. (2017) define accountability as one of the value drivers behind outcomes, this study advances our understanding by explaining the process through which accountability spread emerges and develops, step by step.

Finally, several lines of research that exists at the intersection but are not entirely connected are linked: servitization and open business models, servitization and open service innovation, servitization and business model change (Kortmann and Piller, 2016; Randhawa et al., 2016). In addition, this study offers some insights that are relevant to platform literature. Accountability spread is conceptualized as a factor that should be considered in conjunction with the shift to open platforms (Dattée et al., 2017; Gawer, 2014).

\subsection{Managerial contributions}

In managerial terms, this paper makes three important contributions. First, the paper identifies the critical sources of value creation as well as the risks and uncertainties that firms are required to manage if they are to successfully make the shift to services and innovate their business models. Second, the paper highlights the reasons why servitization can be challenging, especially for asset-heavy complex manufacturing firms. Third, understanding the process helps to shed light on the capabilities that are needed to support this shift: (i) capabilities to understand customer's needs; (ii) capabilities to work with suppliers and partners; and (iii) capabilities to identify sources of accountability spread, and to monitor and manage them.
The first set of capabilities is concerned with the extent to which the firm really understands and is able to articulate the customer's business needs. Often phrased in terms of outcome or contracting for capability, the notion here is that truly understanding the customer's business needs is a pre-requisite for developing an appropriate service or solution. Gaining this in-depth understanding requires the firm to 'walk in the customer's shoes', delving into the essence of its business model and how value is created. The second set of capabilities recognizes that rarely does a single firm possess the entire set of skills required to support a particular service or solution. This is becoming a more acute problem as the complexity of technology and its associated applications grows. A consequence is that, increasingly, firms have to open up the boundaries of their business and work more closely with a set of complementary ecosystems partners. Identifying who these partners should be, what role they should play, and how best to coordinate effort between them becomes critical. The final set of capabilities relates to the concept of accountability spread. The issue here is that, as firms take on more responsibility for delivery - e.g. contract for outcomes they simultaneously involve other firms (over which they have limited control) in the delivery. Consequently, the firm has additional responsibility but reduced control, which inevitably increases risk and exposure.

\subsection{Limitations and further avenues of research}

The research reported in this paper has some limitations. Relying on twelve case studies makes it possible to obtain fine-grained insights with respect to market strategy change and business model change, but it introduces limitations on generalizability. Translating the findings obtained into larger-scale research efforts - with the aim of assessing the performance impact of different combinations of market strategy business model choices would certainly be a valid next step. Furthermore, focus has been on the value creation of firms that undergo changes in market strategy and in their business models, with less concentration on the value-creating implications of the customer. Finally, this study is one of the first studies to provide empirical evidence of step-wise interplay between service-market strategy change and business-model innovation; further research in this area is needed. Specific areas of interest include the geographic aspects of 'opening up' the business model that follows servitization, and the use of the platform approach that accompanies this change.

\section{Acknowledgements}

The authors would like to thank the Cambridge Service Alliance partners for its valuable support; in particular, we are most grateful to leaders from BAE Systems, Caterpillar, IBM for their sharply focused guidance and intellectual input. We gratefully acknowledge the insightful comments of colleagues at the Academy of Management conference, Strategic Management Society conference, Cambridge Service Week conference and the anonymous reviewers, which have proved extremely beneficial in bringing this paper to fruition. Finally, a special thank you to Alan Anderson for his support during several rounds of proofreading.

\section{Appendix}

See Appendix Table A1 and A2. 


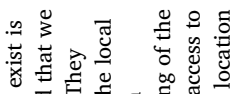

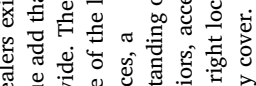

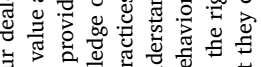

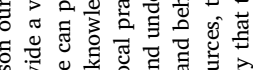

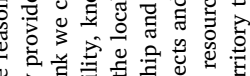

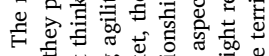

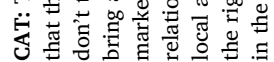

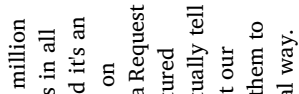

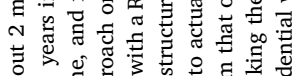

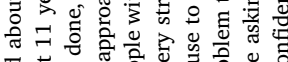

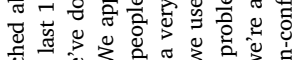

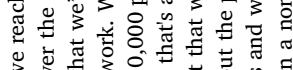

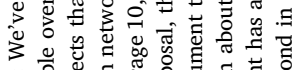

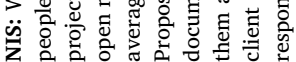

范

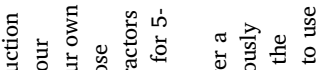

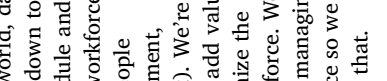

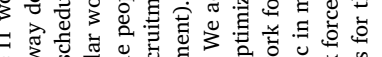

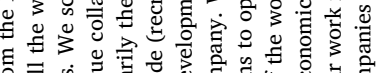

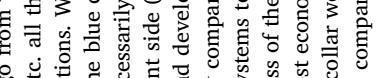

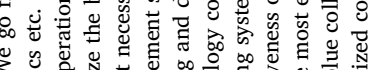

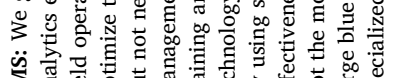

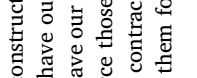

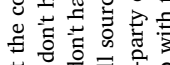

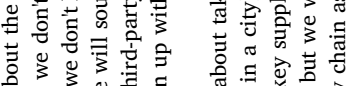

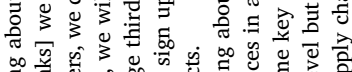

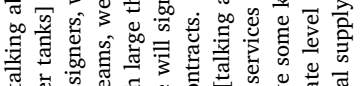

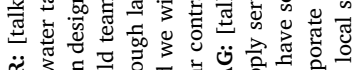

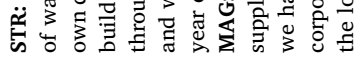

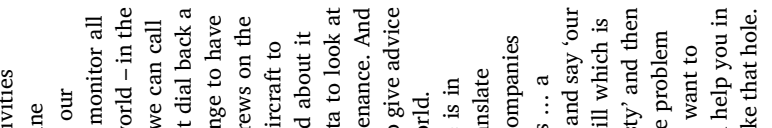

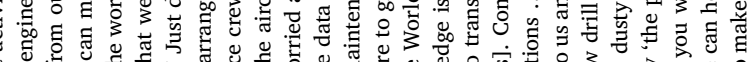

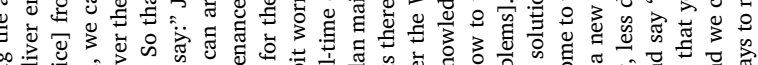

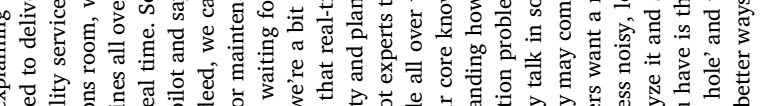

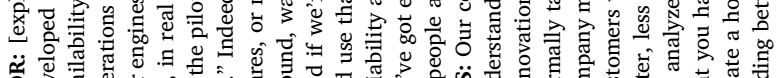

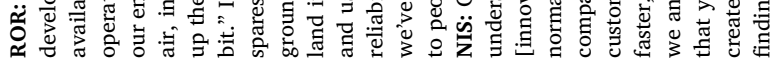

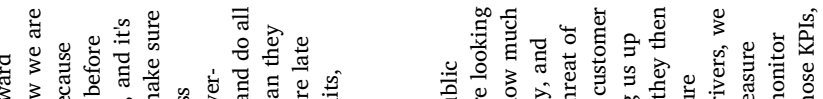

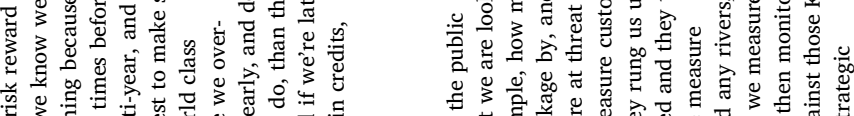

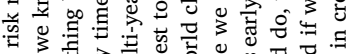

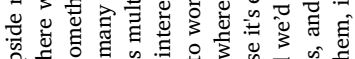

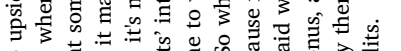

政

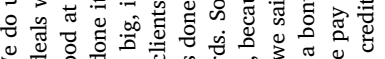

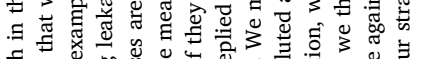

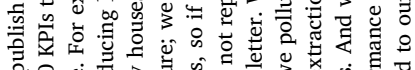

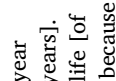

西

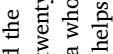

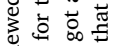

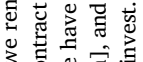

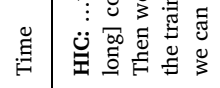

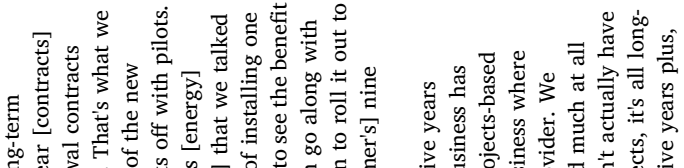

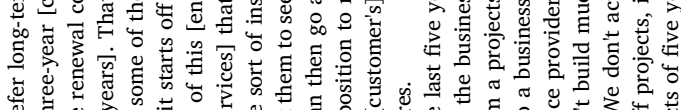

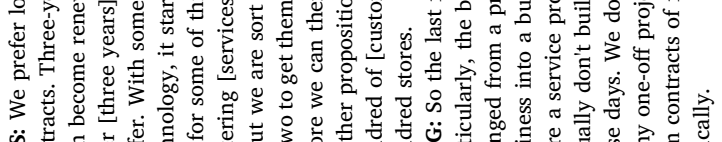

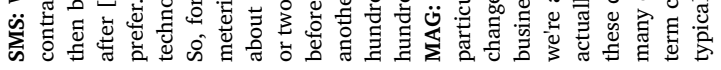

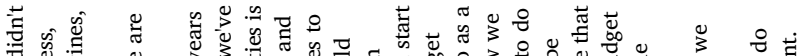

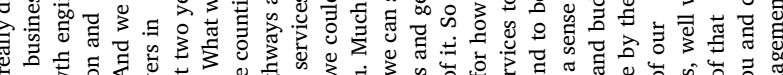

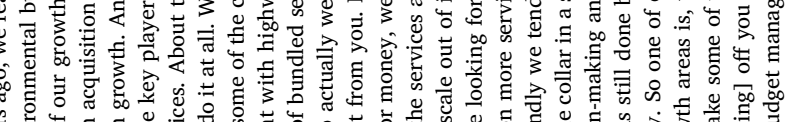

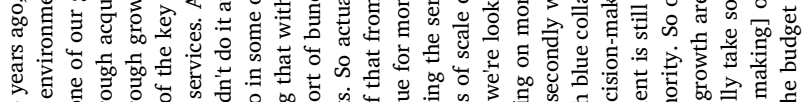

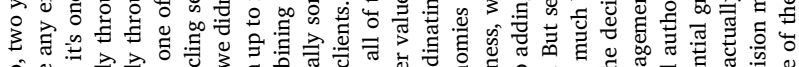

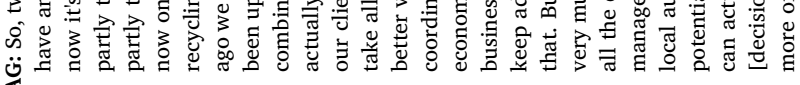




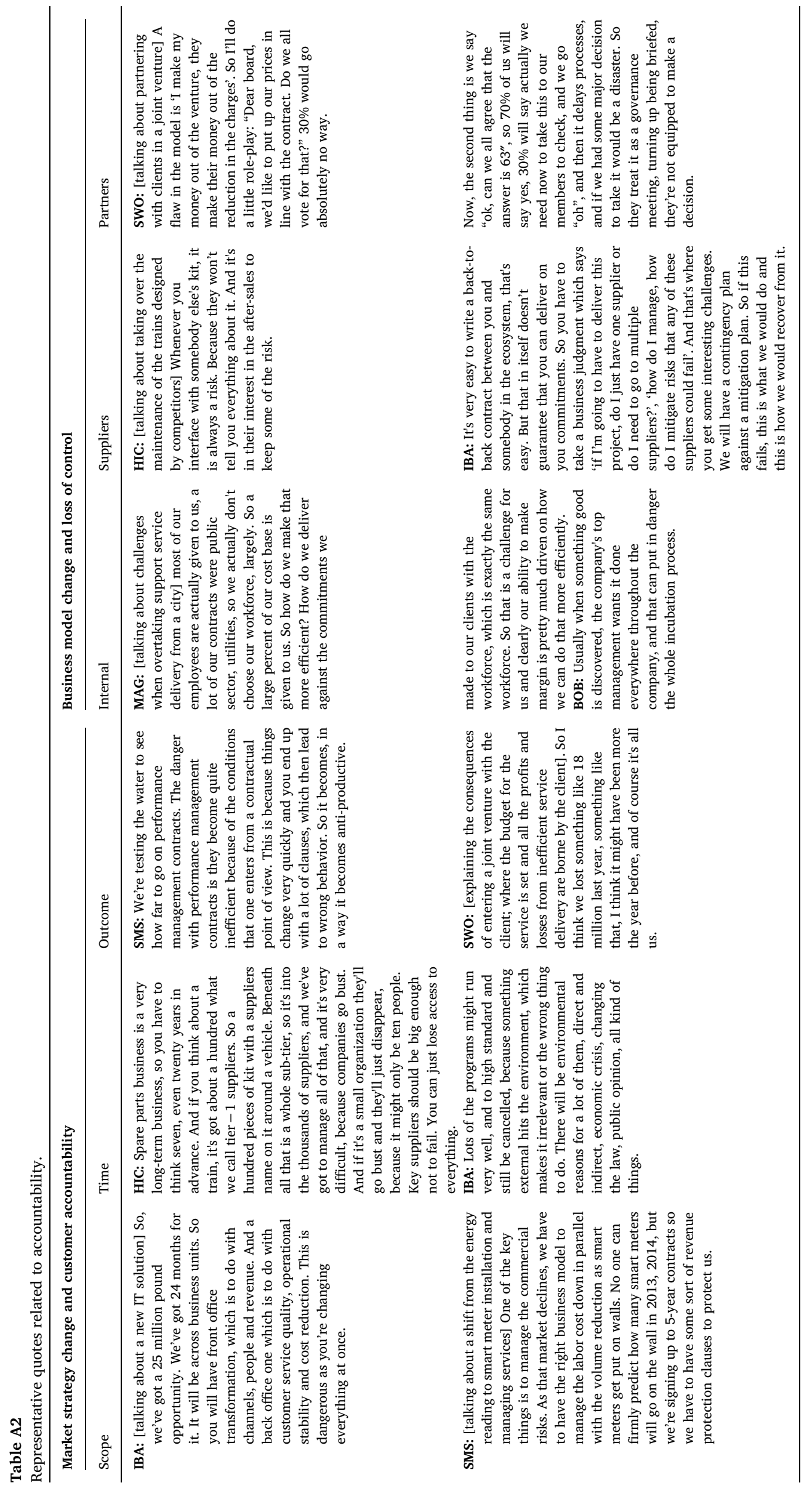




\section{References}

Alexy, O., West, J., Klapper, H., Reitzig, M., 2017. Surrendering control to gain advantage: reconciling openness and the resource-based view of the firm. Strateg. Manag. J. http://dx.doi.org/10.1002/smj.2706.

Amit, R., Zott, C., 2001. Value creation in e-business. Strateg. Manag. J. 22, 493-520. http://dx.doi.org/10.1002/smj.187.

Amit, R., Zott, C., 2012. Creating value through business model innovation. MIT Sloan Manag. Rev 53, 41. http://dx.doi.org/10.2139/ssrn.1701660.

Anderson, J.C., Narus, J.A., 1995. Capturing the value of supplementary services. Harv. Bus. Rev. 73, 75-83.

Antioco, M., Moenaert, R.K., Lindgreen, A., Wetzels, M.G.M., 2008. Organizational antecedents to and consequences of service business orientations in manufacturing companies. J. Acad. Mark. Sci. 36, 337-358. http://dx.doi.org/10.1007/s11747-0080085-1.

Appleyard, M.M., Chesbrough, H.W., 2017. The dynamics of open strategy: from adoption to reversion. Long. Range Plann. 50, 310-321. http://dx.doi.org/10.1016/j.lrp.2016. 07.004.

Baden-Fuller, C., Haefliger, S., 2013. Business models and technological innovation. Long. Range Plann. 46, 419-426. http://dx.doi.org/10.1016/j.lrp.2013.08.023.

Baines, T., Ziaee Bigdeli, A., Bustinza, O.F., Shi, V.G., Baldwin, J., Ridgway, K., 2017. Servitization: revisiting the state-of-the-art and research priorities. Int. J. Oper. Prod. Manag. 37, 256-278. http://dx.doi.org/10.1108/IJOPM-06-2015-0312.

Batista, L., Davis-Poynter, S., Ng, I., Maull, R., 2016. Servitization through outcome-based contract? A systems perspective from the defence industry. Int. J. Prod. Econ. http:// dx.doi.org/10.1016/j.ijpe.2016.12.005.

Benedettini, O., Neely, A., Swink, M., 2015. Why do servitized firms fail? A risk-based explanation. Int. J. Oper. Prod. Manag. 35, 946-979. http://dx.doi.org/10.1108/ IJOPM-02-2014-0052.

Bharadwaj, S.G., Varadarajan, P.R., Fahy, J., 1993. Sustainable competitive advantage in service industries: a conceptual model and research propositions. J. Mark. 57, 83-99. http://dx.doi.org/10.2307/1252221.

Birks, M., Mills, J., 2011. Grounded Theory: A Practical Guide. Sage Publications Ltd. Burton, J., Story, V.M., Zolkiewski, J., Raddats, C., Baines, T., Medway, D., 2016. Identifying tensions in the servitized value chain. Res. Technol. Manag. 59, 38-47.

Bustinza, O.F., Parry, G., Vendrell-Herrero, F., 2013. Supply and demand chain management: the effect of adding services to product offerings. Supply Chain Manag. 18, 618-629. http://dx.doi.org/10.1108/SCM-05-2013-0149.

Casadesus-Masanell, R., Ricart, J.E., 2010. From strategy to business models and onto tactics. Long. Range Plann. 43, 195-215. http://dx.doi.org/10.1016/j.lrp.2010.01. 004.

Chase, R.B., 1981. The customer contact approach to services: theoretical bases and practical extensions. Oper. Res. 29, 698-706. http://dx.doi.org/10.1287/opre.29.4. 698.

Chesbrough, H., 2007. Business model innovation: it's not just about technology anymore. Strateg. Leadersh. 35, 12-17. http://dx.doi.org/10.1108/10878570710833714.

Chesbrough, H., 2010. Business model innovation: opportunities and barriers. Long. Range Plann. 43, 354-363. http://dx.doi.org/10.1016/j.lrp.2009.07.010.

Chesbrough, H., 2012. Why companies should have open business models. MIT Sloan Manag. Rev. 48, 23 .

Chesbrough, H., Rosenbloom, R.S., 2002. The role of the business model in capturing value from innovation: evidence from Xerox Corporation's technology spin-off companies. Ind. Corp. Chang 11, 529-555. http://dx.doi.org/10.1093/icc/11.3.529.

Chesbrough, H.W., 2006. Open Business Models: How to Thrive in the New Innovation Landscape. Harvard Business Review Press.

Chesbrough, H.W., 2007. Have open business models. MIT Sloan Manag. Rev. 48, 22-28. http://dx.doi.org/10.1111/j.1540-5885.2008.00309_1.x.

Chesbrough, H.W., 2011. Open Services Innovation: Rethinking Your Business to Grow and Compete in a New Era, 1st ed. Jossey-Bass.

Corbin, J.M., Strauss, A., 1990. Grounded theory research: procedures, canons, and evaluative criteria. Qual. Sociol. 13, 3-21. http://dx.doi.org/10.1007/BF00988593.

Cusumano, M.A., Kahl, S.J., Suarez, F.F., 2015. Services, industry evolution, and the competitive strategies of product firms. Strateg. Manag. J. 36, 559-575. http://dx. doi.org/10.1002/smj.2235.

Dattée, B., Alexy, O., Autio, E., 2017. Maneuvering in poor visibility: how firms play the ecosystem game when uncertainty is high. Acad. Manag. J. amj. 2015, 0869. http:// dx.doi.org/10.5465/amj.2015.0869.

Davies, A., Brady, T., Hobday, M., 2006. Charting a path toward integrated solutions. MIT Sloan Manag. Rev. 43, 39-48. http://dx.doi.org/10.1225/SMR202.

Davies, A., Brady, T., Hobday, M., 2007. Organizing for solutions: systems seller vs. systems integrator. Ind. Mark. Manag. 36, 183-193. http://dx.doi.org/10.1016/j. indmarman.2006.04.009.

Demil, B., Lecocq, X., 2010. Business model evolution: in search of dynamic consistency. Long Range Plann. 43, 227-246. http://dx.doi.org/10.1016/j.lrp.2010.02.004.

Desyllas, P., Sako, M., 2013. Profiting from business model innovation: evidence from pay-as-you-drive auto insurance. Res. Policy 42, 101-116. http://dx.doi.org/10. 1016/j.respol.2012.05.008.

Edmondson, A.C., Mcmanus, S.E., 2007. Methodological fit in management field research. Acad. Manag. Rev. 32, 1155-1179. http://dx.doi.org/10.5465/AMR.2007 26586086.

Eggert, A., Hogreve, J., Ulaga, W., Muenkhoff, E., 2014. Revenue and profit implications of industrial service strategies. J. Serv. Res. 17, 23-39. http://dx.doi.org/10.1177/ 1094670513485823.

Eisenhardt, K.M., 1989. Building theories from case study research. Acad. Manag. Rev. 14, 532-550. http://dx.doi.org/10.5465/AMR.1989.4308385.
Eisenhardt, K.M., Graebner, M.E., 2007. Theory building from cases: opportunities and challenges. Acad. Manag. J. 50, 25-32. http://dx.doi.org/10.5465/AMJ.2007. 24160888

Fang, E. (Er), Palmatier, R.W., Steenkamp, J.-B.E., 2008. Effect of service transition strategies on firm value. J. Mark. 72, 1-14. http://dx.doi.org/10.1509/jmkg.72.5.1.

Forkmann, S., Henneberg, S.C., Witell, L., Kindström, D., 2017a. Driver configurations for successful service infusion (109467051770616). J. Serv. Res. http://dx.doi.org/10. 1177/1094670517706160.

Forkmann, S., Ramos, C., Henneberg, S.C., Naudé, P., 2017b. Understanding the service infusion process as a business model reconfiguration. Ind. Mark. Manag. 60, 151-166. http://dx.doi.org/10.1016/j.indmarman.2016.05.001.

Foss, N.J., Saebi, T., 2017. Fifteen years of research on business model innovation: how far have we come, and where should we go? J. Manag. 43, 200-227. http://dx.doi. org/10.1177/0149206316675927.

Gambardella, A., McGahan, A.M., 2010. Business-model innovation: general purpose technologies and their implications for industry structure. Long. Range Plann. 43, 262-271. http://dx.doi.org/10.1016/j.lrp.2009.07.009.

Gawer, A., 2014. Bridging differing perspectives on technological platforms: toward an integrative framework. Res. Policy. http://dx.doi.org/10.1016/j.respol.2014.03.006.

Gawer, A., Cusumano, M.A., 2002. Platform Leadership: How Intel, Microsoft, and Cisco Drive Industry Innovation. Harvard Business Review Press.

Gebauer, H., Paiola, M., Saccani, N., 2013. Characterizing service networks for moving from products to solutions. Ind. Mark. Manag. 42, 31-46. http://dx.doi.org/10.1016/ j.indmarman.2012.11.002.

Gianiodis, P.T., Ettlie, J.E., Urbina, J.J., 2014. Open Service Innovation in the Global Banking Industry: Inside-Out Versus Outside-In Strategies. Acad. Manag. Perspect. 28, 76-91. http://dx.doi.org/10.5465/amp.2012.0126.

Glaser, B.G., Strauss, A., 1967. The Discovery of Grounded Theory: Strategies for Qualitative Research. Aldine Publishing Co., Chicago, IL.

Hacklin, F., Björkdahl, J., Wallin, M.W., 2017. Strategies for business model innovation: how firms reel in migrating value. Long. Range Plann. http://dx.doi.org/10.1016/j. lrp.2017.06.009.

Hienerth, C., Keinz, P., Lettl, C., 2012. Exploring the nature and implementation process of IT-based user-centric business models. Long. Range Plann. 44, 344-374. http://dx. doi.org/10.1016/j.lrp.2011.09.009.

von Hippel, E., von Krogh, G., 2003. Innovation model: issues for organization science open source software and the " private-collective" innovation model: issues for organization science. Organ. Sci. 14, 209-223. http://dx.doi.org/10.1287/orsc.14.2. 209.14992.

Howard, M., Wu, Z., Caldwell, N., Jia, F., König, C., 2016. Performance-based contracting in the defence industry: exploring triadic dynamics between government, OEMs and suppliers. Ind. Mark. Manag. 59, 63-75. http://dx.doi.org/10.1016/j.indmarman. 2016.05.030.

Johnson, M.W., Christensen, C.M., Kagermann, H., 2008. Reinventing your business model. Harv. Bus. Rev. 86, 50-60. http://dx.doi.org/10.1111/j.0955-6419.2005. 00347.x.

Josephson, B.W., Johnson, J.L., Mariadoss, B.J., Cullen, J., 2016. Service transition strategies in manufacturing: implications for firm risk. J. Serv. Res. 19, 142-157. http://dx.doi.org/10.1177/1094670515600422.

Jovanovic, M., Engwall, M., Jerbrant, A., 2016. Matching service offerings and product operations: a key to servitization success. Res. Manag. 59, 29-36. http://dx.doi.org/ 10.1080/08956308.2016.1161403.

Kindström, D., 2010. Towards a service-based business model - key aspects for future competitive advantage. Eur. Manag. J. 28, 479-490. http://dx.doi.org/10.1016/j emj.2010.07.002.

Kohtamäki, M., Partanen, J., Parida, V., Wincent, J., 2013. Non-linear relationship between industrial service offering and sales growth: the moderating role of network capabilities. Ind. Mark. Manag. 42, 1374-1385. http://dx.doi.org/10.1016/j. indmarman.2013.07.018.

Kortmann, S., Piller, F., 2016. Open business models and closed-loop value chains: redefining the firm-consumer relationship. Calif. Manag. Rev. 58, 88-108. http://dx doi.org/10.1525/cmr.2016.58.3.88.

Kowalkowski, C., Gebauer, H., Oliva, R., 2017. Service growth in product firms: past, present, and future. Ind. Mark. Manag. http://dx.doi.org/10.1016/j.indmarman. 2016.10.015.

Kvale, S., 1996. InterViews: An Introduction to Qualitative Research Interviewing. Sage Publications Ltd, London.

Martins, L.L., Rindova, V.P., Greenbaum, B.E., 2015. Unlocking the hidden value of concepts: a cognitive approach to business model innovation. Strateg. Entrep. J. 9, 99-117. http://dx.doi.org/10.1002/sej.

Massa, L., Tucci, C., Afuah, A., 2017. A critical assessment of business model research Acad. Manag. Ann. 11, 73-104. http://dx.doi.org/10.5465/annals.2014.0072.

Neely, A., 2008. Exploring the financial consequences of the servitization of manufacturing. Oper. Manag. Res. 1, 103-118. http://dx.doi.org/10.1007/s12063-0090015-5.

Ng, I.C.L., Maull, R., Yip, N., 2009. Outcome-based contracts as a driver for systems thinking and service-dominant logic in service science: evidence from the defence industry. Eur. Manag. J. 27, 377-387. http://dx.doi.org/10.1016/j.emj.2009.05.002.

Ng, I.C.L., Ding, D.X., Yip, N., 2013. Outcome-based contracts as new business model: the role of partnership and value-driven relational assets. Ind. Mark. Manag. 42, 730-743. http://dx.doi.org/10.1016/j.indmarman.2013.05.009.

Oliva, R., Kallenberg, R., 2003. Managing the transition from products to services. Int. J. Serv. Ind. Manag. 14, 160-172. http://dx.doi.org/10.1108/09564230310474138.

Paiola, M., Saccani, N., Perona, M., Gebauer, H., 2013. Moving from products to solutions: strategic approaches for developing capabilities. Eur. Manag. J. 31, 390-409. http://dx.doi.org/10.1016/j.emj.2012.10.002. 
Paula, A., Barquet, B., Oliveira, M.G., De, Amigo, C.R., Cunha, V.P., Rozenfeld, H., 2013. Industrial marketing management employing the business model concept to support the adoption of product - service systems ( PSS). Ind. Mark. Manag. 42, 693-704. http://dx.doi.org/10.1016/j.indmarman.2013.05.003.

Priem, R.L., Wenzel, M., Koch, J., 2017. Demand-side strategy and business models: putting value creation for consumers center stage. Long. Range Plann. http://dx.doi. org/10.1016/j.lrp.2017.07.007.

Rabetino, R., Harmsen, W., Kohtamäki, M., Sihvonen, J., 2018. Structuring servitizationrelated research. Int. J. Oper. Prod. Manag. 38, 350-371. http://dx.doi.org/10.1108/ IJOPM-03-2017-0175.

Raddats, C., Burton, J., Ashman, R., 2015. Resource configurations for services success in manufacturing companies. J. Serv. Manag. 26, 97-116. http://dx.doi.org/10.1108/ JOSM-12-2012-0278.

Randhawa, K., Wilden, R., Hohberger, J., 2016. A Bibliometric Review of Open Innovation: Setting a Research Agenda. J. Prod. Innov. Manag. 33, 750-772. http:// dx.doi.org/10.1111/jpim.12312.

Reim, W., Parida, V., Örtqvist, D., 2015. Product-Service Systems (PSS) business models and tactics- A systematic literature review. J. Clean. Prod. 97, 61-75. http://dx.doi. org/10.1016/j.jclepro.2014.07.003.

Reim, W., Parida, V., Sjödin, D.R., 2016. Risk management for product-service system operation. Int. J. Oper. Prod. Manag. 36, 665-686. http://dx.doi.org/10.1108/ IJOPM-10-2014-0498.

Rönnberg Sjödin, D., Parida, V., Kohtamäki, M., 2016. Capability configurations for advanced service offerings in manufacturing firms: using fuzzy set qualitative comparative analysis. J. Bus. Res. 69, 5330-5335. http://dx.doi.org/10.1016/j.jbusres. 2016.04.133.

Saebi, T., Foss, N.J., 2015. Business models for open innovation: matching heterogeneous open innovation strategies with business model dimensions. Eur. Manag. J. 33 201-213. http://dx.doi.org/10.1016/j.emj.2014.11.002.

Sanchez, P., Ricart, J.E., 2010. Business model innovation and sources of value creation in low-income markets. Eur. Manag. Rev. 7, 138-154. http://dx.doi.org/10.1057/emr. 2010.16 .

Santamaría, L., Jesús Nieto, M., Miles, I., 2012. Service innovation in manufacturing firms: evidence from Spain. Technovation 32, 144-155. http://dx.doi.org/10.1016/j technovation.2011.08.006.

Sawhney, M., Balasubramanian, S., Krishnan, V.V., 2004. Creating growth with services. MIT Sloan Manag. Rev, 45, 34-43.

Sinfield, J.V., Calder, E., McConnell, B., Colson, S., 2012. How to identify new business models. MIT Sloan Manag. Rev. 53, 85-90.

Slywotzky, A.J., 1996. Value Migration: How to Think Several Moves Ahead of the Competition. Harvard Business School Press.

Sosna, M., Trevinyo-Rodríguez, R.N., Velamuri, S.R., 2010. Business model innovation through trial-and-error learning. Long. Range Plann. 43, 383-407. http://dx.doi.org/ 10.1016/j.lrp.2010.02.003.

Sousa, R., da Silveira, G.J.C., 2017. Capability antecedents and performance outcomes of servitization. Int. J. Oper. Prod. Manag. 37, 444-467. http://dx.doi.org/10.1108/ IJOPM-11-2015-0696.

Story, V.M., Raddats, C., Burton, J., Zolkiewski, J., Baines, T., 2017. Capabilities for advanced services: a multi-actor perspective. Ind. Mark. Manag. 60, 54-68. http://dx. doi.org/10.1016/j.indmarman.2016.04.015.

Suarez, F.F., Cusumano, M.A., Kahl, S.J., 2013. Services and the business models of product firms: an empirical analysis of the software industry. Manag. Sci. 59,
420-435. http://dx.doi.org/10.1287/mnsc.1120.1634.

Suddaby, R., 2006. What grounded theory is not. Acad. Manag. J. 49, 633-642 (doi:Editorial).

Teece, D.J., 2010. Business models, business strategy and innovation. Long. Range Plann. 43, 172-194. http://dx.doi.org/10.1016/j.lrp.2009.07.003.

Tongur, S., Engwall, M., 2014. The business model dilemma of technology shifts. Technovation 34, 525-535. http://dx.doi.org/10.1016/j.technovation.2014.02.006.

Tushman, M., Lakhani, K.R., Lifshitz-Assaf, H., 2012. Open innovation and organization design. J. Organ. Des. 1, 24. http://dx.doi.org/10.7146/jod.6336.

Ulaga, W., Eggert, A., 2006. Value-based differentiation in business relationships: gaining and sustaining key supplier status. J. Mark. 70, 119-136. http://dx.doi.org/10.1509/ jmkg.2006.70.1.119.

Vandermerwe, S., Rada, J., 1988. Servitization of business: adding value by adding services. Eur. Manag. J. 6, 314-324. http://dx.doi.org/10.1016/0263-2373(88) 90033-3.

Velu, C., 2015. Business model innovation and third-party alliance on the survival of new firms. Technovation 35, 1-11. http://dx.doi.org/10.1016/j.technovation.2014.09. 007.

Vendrell-Herrero, F., Bustinza, O.F., Parry, G., Georgantzis, N., 2017. Servitization, digitization and supply chain interdependency. Ind. Mark. Manag. 60, 69-81. http:// dx.doi.org/10.1016/j.indmarman.2016.06.013.

Visnjic, I., Wiengarten, F., Neely, A., 2016. Only the brave: product innovation, service business model innovation, and their impact on performance. J. Prod. Innov. Manag. 33, 36-52. http://dx.doi.org/10.1111/jpim.12254.

Visnjic, I., Jovanovic, M., Neely, A., Engwall, M., 2017. What brings the value to outcomebased contract providers? Value drivers in outcome business models. Int. J. Prod. Econ. 192, 169-181. http://dx.doi.org/10.1016/j.ijpe.2016.12.008.

Visnjic Kastalli, I., Van Looy, B., 2013. Servitization: disentangling the impact of service business model innovation on manufacturing firm performance. J. Oper. Manag. 31, 169-180. http://dx.doi.org/10.1016/j.jom.2013.02.001.

Visnjic Kastalli, I., Van Looy, B., Neely, A., 2013. Steering manufacturing firms towards service business model innovation. Calif. Manag. Rev. 56, 100-123. http://dx.doi. org/10.1525/cmr.2013.56.1.100.

West, J., Bogers, M., 2014. Leveraging external sources of innovation: a review of research on open innovation. J. Prod. Innov. Manag. http://dx.doi.org/10.1111/jpim. 12125.

Willemstein, L., van der Valk, T., Meeus, M.T.H., 2007. Dynamics in business models: an empirical analysis of medical biotechnology firms in the Netherlands. Technovation 27, 221-232. http://dx.doi.org/10.1016/j.technovation.2006.08.005.

Wise, R., Baumgartner, P., 1999. Go downstream: the new profit imperative in manufacturing. Harv. Bus. Rev. 77, 133-141.

Witell, L., Löfgren, M., 2013. From service for free to service for fee: business mode innovation in manufacturing firms. J. Serv. Manag. 24, 520-533. http://dx.doi.org/ 10.1108/JOSM-04-2013-0103.

Yin, R.K., 1994. Case Study Research: Design and Methods (Applied Social Research Methods). Newbury Park CA Sage.

Zott, C., Amit, R., 2008. The fit between product market strategy and business model: implications for firm performance. Strateg. Manag. J. 29, 1-26. http://dx.doi.org/10 1002/smj.642.

Zott, C., Amit, R., 2010. Business model design: an activity system perspective. Long. Range Plann. 43, 216-226. http://dx.doi.org/10.1016/j.lrp.2009.07.004. 